\title{
The Relation between Platelet to Lymphocyte Ratio with Severity And Complexity of Coronary Heart Disease in Patients with Acute ST- Segment Elevation Myocardial Infarction Undergoing Primary Percutaneous Coronary Intervention
}

\author{
NEDAA E. EL-DEN, M.Sc.; AYMAN A. GAFAR, M.D.; MOHAMED A. HENDIA, M.D. and \\ MAGDY M. EL-MASRY, M.D.
}

The Department of Cardiology, Faculty of Medicine, Tanta University

\begin{abstract}
Background: Coronary Artery Disease (CAD) is characterized pathologically by atherosclerosis formation which is the predominant cause of death. The chronic inflammatory response is associated with production of platelets and lymphocytes, elevated platelet counts accelerate atherosclerosis formation, progression, and destabilization of atherosclerotic plaques. The ratio of absolute number of platelets to the number of lymphocyte (PLR) act as an effective biomarker to predict the severity of CAD.
\end{abstract}

Aim of Study: To study the relation between Platelet to Lymphocyte Ratio (PLR) with severity and complexity of coronary heart disease in patients with acute ST-segment Elevation Myocardial Infarction (STEMI) undergoing primary Percutaneous Coronary Intervention (PCI).

Methods: This study was conducted on 100 patients diagnosed with STEMI and who underwent primary PCI in Tanta University Hospitals, Cardiovascular Department, from June 2017 to December 2017. To assess the correlation between platelet to lymphocyte parameters and severity of CAD, the sample was divided according to the angiographic severity of CAD by using Gensini score into three groups, Group I Gensini score ranged from zero to 50, Group II Gensini score ranged from 50 to 100 and Group III Gensini score more than 100.

Results: Patients with high PLR showed significant tachycardia at onset of admission, higher glucose level, higher Killip class II-IV, lower final angiographic TIMI flow, higher Gens iniscore, higher serum LDL level, lower HDL levels and higher triglycerides level, higher all the composite endpoints of Major Adverse Cardiovascular Events (MACE) including death, reinfarction and Congestive Heart Failure (CHF).

Conclusion: Platelets to lymphocytes ratio is an independent prognostic factor for severity and complexity of CAD in patients with STEMI undergoing primary PCI intervention by using Gensini score.

Correspondence to: Dr. Nedaa E. El-Den, The Department of Cardiology, Faculty of Medicine, Tanta University
Key Words: Coronary artery disease - ST segment elevation acute myocardial infarction - Platelet to lymphocytes ratio - Congestive heart failure.

\section{Introduction}

CORONARY Artery Disease (CAD) is characterized pathologically by atherosclerosis formation which is the predominant cause of death [1]. The chronic inflammatory response is associated with production of platelets and lymphocytes, elevated platelet counts accelerate atherosclerosis formation, progression, and destabilization of atherosclerotic plaques. Platelets act as a bridge between local inflammation at the vascular wall and development of atherosclerotic plaques [2]. Platelets are activated by substances released from cells of the vascular wall and secrete pro inflammatory chemokines and cytokines associated with vascular inflammation that developed atherothrombotic disease [3]. Low lymphocyte count accelerate the progression of atherosclerosis and worse cardiovascular consequences in patients with CAD [4]. Therefore, the ratio of absolute number of platelets to the number of lymphocyte (PLR) act as an effective biomarker to predict the severity of CAD [5]. Patients with a high pre-procedural PLR level show positive association with the Gensini score, which is the scoring methods in assessing CAD severity [6]

\section{Aim of the work:}

The aim of this work was to study the relation between platelet to lymphocyte ratio and the severity and complexity of coronary heart disease in patients with acute ST-segment Elevation Myocardial Infarction (STEMI) undergoing primary Percutaneous Coronary Intervention (PCI). 


\section{Patients and Methods}

This study was conducted on 100 patients of both gender diagnosed with STEMI and who underwent primary PCI at Cardiology Department at Tanta University Hospital from June 2017 to December 2017.

All patients were subjected to detailed history taking, full clinical examination, 12 lead electrocardiogram, echocardiography and primary PCI strategy. Blood samples were collected on admission before PCI from the ante-cubital vein. Platelets to Lymphocytes Ratio (PLR) was calculated by dividing platelets count to lymphocytes count from the same blood sample obtained before primary PCI.

To assess the correlation between PLR and severity of CAD, the sample was divided according to angiographic finding by using Gensini score into three groups, Group I Gensini score ranged from zero to 50, Group II Gensini score ranged from 50 to 100 and Group III Gensini score more than 100 .

Exclusion criteria included patients with prior myocardial infarction, patients who previously underwent Coronary Artery Bypass Graft (CABG) or PCI, patients with end stage renal failure (creatinine clearance $<15 \mathrm{~mL} / \mathrm{min}$ ), patients with hematological disorders, patients with active hepatobiliary disease, patients with active infections, patients with neoplastic diseases, patients with recent major surgical procedure or trauma and patients with known dyslipidemia.

Patients in each group were matched to other groups regarding different demographic, clinical and laboratory parameters.

Duration of the study: This study was done in a period of six months from June 2017 to December 2017.

\section{Statistical analysis:}

Data were fed to the computer and analyzed using IBM SPSS software package Version 20.0. Qualitative data were described using number and percent. Quantitative data were described using range (minimum and maximum), mean, standard deviation and median. Significance of the obtained results was judged at the 5\% level.

\section{Results}

Patient demographics: Regarding the gender: Seventy-six patients (76\%) of the study population were males and twenty-four patients $(24 \%)$ were females; there was no statistically significant difference between the three groups ( $p$-value $=0.781)$. Regarding the age: The age of the study population ranged from 30 to 85 years with a mean of $57.01 \pm$ 11.38 years, and there was no statistically significant difference between the three groups $(p$-value $=$ 0.543), Table (1).

Table (1): Comparison between the different studied groups according to demographic data.

\begin{tabular}{|c|c|c|c|c|c|c|c|c|c|c|}
\hline & \multicolumn{2}{|c|}{$\begin{array}{c}\text { Total } \\
(n=100)\end{array}$} & \multicolumn{2}{|c|}{$\begin{array}{l}\text { Group I } \\
(n=43)\end{array}$} & \multicolumn{2}{|c|}{$\begin{array}{c}\text { Group II } \\
(\mathrm{n}=35)\end{array}$} & \multicolumn{2}{|c|}{$\begin{array}{c}\text { Group III } \\
(\mathrm{n}=22)\end{array}$} & \multirow{2}{*}{$\begin{array}{l}\text { Test } \\
\text { of sig. }\end{array}$} & \multirow{2}{*}{$p$} \\
\hline & No. & $\%$ & No. & $\%$ & No. & $\%$ & No. & $\%$ & & \\
\hline \multicolumn{11}{|l|}{ Sex: } \\
\hline Male & 76 & 76.0 & 32 & 74.4 & 28 & 80.0 & 16 & 72.7 & $\chi^{2}=$ & \\
\hline Female & 24 & 24.0 & 11 & 25.6 & 7 & 20.0 & 6 & 27.3 & 0.495 & 0.781 \\
\hline \multicolumn{11}{|l|}{ Age (years): } \\
\hline Min.-max. & \multicolumn{2}{|c|}{$30.0-85.0$} & \multicolumn{2}{|c|}{$34.0-80.0$} & \multicolumn{2}{|c|}{$30.0-85.0$} & \multicolumn{2}{|c|}{$45.0-85.0$} & $\mathrm{~F}=$ & \\
\hline Mean \pm SD. & \multicolumn{2}{|c|}{$57.01 \pm 11.38$} & \multicolumn{2}{|c|}{$55.91 \pm 10.51$} & \multicolumn{2}{|c|}{$56.97 \pm 12.52$} & \multicolumn{2}{|c|}{$59.23 \pm 11.33$} & 0.615 & 0.543 \\
\hline Median & \multicolumn{2}{|c|}{56.50} & \multicolumn{2}{|l|}{57.0} & \multicolumn{2}{|l|}{58.0} & \multicolumn{2}{|l|}{56.0} & & \\
\hline
\end{tabular}

Prevalence of risk factors: Regarding diabetes mellitus: Thirty-one patients (31\%) of the study population were diabetic, and there was no statistically significant difference between the studied groups $(p$-value $=0.056)$. Regarding systemic hypertension: Thirty-two patients (32\%) of the study population were hypertensive. There was no statistically significant difference between the studied groups $(p$-value $=0.266)$. Regarding Smoking: Fifty-four patients (54\%) of the study 
population were smokers. There was no statistically significant difference between the studied groups $(p$-value $=0.223)$, Table $(2)$.

Clinical presentation: Regarding the Systolic blood pressure; it ranged between 70.0 and 200.0 $\mathrm{mmHg}$ with a mean of $125.0 \pm 29.22 \mathrm{mmHg}$, there was no statistically significant difference between the three groups $(p$-value $=0.276)$, regarding the diastolic blood pressure; it ranged between 50.0 and $110.0 \mathrm{mmHg}$, with a mean of $77.10 \pm 14.58$ $\mathrm{mmHg}$. There was no statistically significant difference between the three groups $(p$-value $=0.318)$ and regarding the heart rate; it ranged between 40 and 140 beats per minute (bpm) with a mean of $84.15 \pm 17.28$ and there was statistically significant difference between the three groups ( $p$-value $<0.001 *)$. Table (3).

Table (2): Comparison between the different studied groups according to risk factors.

\begin{tabular}{|c|c|c|c|c|c|c|c|c|c|c|}
\hline \multirow[t]{2}{*}{ Risk factors } & \multicolumn{2}{|c|}{$\begin{array}{c}\text { Total } \\
(\mathrm{n}=100)\end{array}$} & \multicolumn{2}{|c|}{$\begin{array}{l}\text { Group I } \\
(n=43)\end{array}$} & \multicolumn{2}{|c|}{$\begin{array}{l}\text { Group II } \\
(\mathrm{n}=35)\end{array}$} & \multicolumn{2}{|c|}{$\begin{array}{c}\text { Group III } \\
(\mathrm{n}=22)\end{array}$} & \multirow[t]{2}{*}{$\chi^{2}$} & \multirow{2}{*}{$p$} \\
\hline & No. & $\%$ & No. & $\%$ & No. & $\%$ & No. & $\%$ & & \\
\hline Diabetes & 31 & 31.0 & 9 & 20.9 & 11 & 31.4 & 11 & 50.0 & 5.754 & 0.056 \\
\hline Hypertension & 32 & 32.0 & 11 & 25.6 & 11 & 31.4 & 10 & 45.5 & 2.650 & 0.266 \\
\hline Smoking & 54 & 54.0 & 19 & 44.2 & 21 & 60.0 & 14 & 63.6 & 2.997 & 0.223 \\
\hline
\end{tabular}

Table (3): Comparison between the different studied groups according to vital sings "clinical".

\begin{tabular}{|c|c|c|c|c|c|c|}
\hline & $\begin{array}{c}\text { Total } \\
(\mathrm{n}=100)\end{array}$ & $\begin{array}{l}\text { Group I } \\
(\mathrm{n}=43)\end{array}$ & $\begin{array}{c}\text { Group II } \\
(\mathrm{n}=35)\end{array}$ & $\begin{array}{c}\text { Group III } \\
(\mathrm{n}=22)\end{array}$ & $\mathrm{F}$ & $p$ \\
\hline \multicolumn{7}{|c|}{ Systolic blood pressure ( $\mathrm{mmHg})$ : } \\
\hline Min.-max. & $70.0-200.0$ & $90.0-170.0$ & $90.0-200.0$ & $70.0-200.0$ & \multirow[t]{3}{*}{1.306} & \multirow[t]{3}{*}{0.276} \\
\hline Mean $\pm \mathrm{SD}$ & $125.0 \pm 29.22$ & $120.47 \pm 22.36$ & $125.71 \pm 29.23$ & $132.7 \pm 39.18$ & & \\
\hline Median & 120.0 & 110.0 & 120.0 & 130.0 & & \\
\hline \multicolumn{7}{|c|}{ Diastolic blood pressure $(\mathrm{mmHg})$ : } \\
\hline Min.-max. & $50.0-110.0$ & $50.0-110.0$ & $60.0-110.0$ & $50.0-110.0$ & \multirow[t]{3}{*}{1.160} & \multirow[t]{3}{*}{0.318} \\
\hline Mean $\pm \mathrm{SD}$ & $77.10 \pm 14.58$ & $74.65 \pm 12.79$ & $78.29 \pm 14.85$ & $80.00 \pm 17.18$ & & \\
\hline Median & 80.0 & 70.0 & 80.0 & 80.0 & & \\
\hline \multicolumn{7}{|l|}{ Pulse (bpm): } \\
\hline Min.-max. & $40.0-140.0$ & $50.0-110.0$ & $40.0-110.0$ & $55.0-140.0$ & \multirow[t]{4}{*}{$10.065^{*}$} & \multirow[t]{4}{*}{$<0.001 *$} \\
\hline Mean $\pm \mathrm{SD}$ & $84.0 \pm 17.28$ & $79.19 \pm 12.72$ & $81.57 \pm 15.61$ & $97.27 \pm 21.14$ & & \\
\hline Median & 80.0 & 80.0 & 80.0 & 100.0 & & \\
\hline Sig.betgrps. & \multicolumn{4}{|c|}{$p_{1}=0.787, p_{2}<0.001 *, p_{3}=0.001$} & & \\
\hline
\end{tabular}

F : ANOVA test pair wise comparison bet. each 2 groups was done using Post Hoc Test (Tukey).

$p: p$-value for comparing between the three groups.

p1: $p$-value for comparing between Group I and Group II.

$p 2: p$-value for comparing between Group I and Group III.

p3: $p$-value for comparing between Group II and Group III.

$*$ : Statistically significant at $p \leq 0.05$.

\section{Regarding Killip class:}

Eighty-five patients of the study population presented with Killip class I (85\%) while fifteen patients presented with Killip class of II-IV (15\%). In Group I, 1 patients presented with Killip class II-IV (2.3\%), while in Group II, thirty-one patients presented with Killip class of I (88.6\%) while four patients presented with Killip class of II-IV (11.4\%), and in Group III, twelve patients of the study population presented with Killip class I (54.4\%) while ten patients presented with Killip class of II-IV (45.5\%). There was statistically significant difference between the studied groups ( $p$-value $<0.001)$, Table (4).

Rregarding the STEMI location; fifty-four patients $(54 \%)$ of the study population presented with anterior STEMI, while 32 patients $(37 \%)$ presented with inferior STEMI and patients (9\%) presented with lateral STEMI. There was statistically significant difference between the three groups ( $p$-value $<0.001 *)$, Table (4). 
Table (4): Comparison between the different studied groups according to Killip class and STEMI location.

\begin{tabular}{|c|c|c|c|c|c|c|c|c|c|c|}
\hline & \multicolumn{2}{|c|}{$\begin{array}{c}\text { Total } \\
(n=100)\end{array}$} & \multicolumn{2}{|c|}{$\begin{array}{l}\text { Group I } \\
(n=43)\end{array}$} & \multicolumn{2}{|c|}{$\begin{array}{l}\text { Group II } \\
(n=35)\end{array}$} & \multicolumn{2}{|c|}{$\begin{array}{l}\text { Group III } \\
(n=22)\end{array}$} & \multirow[t]{2}{*}{$x^{2}$} & \multirow[t]{2}{*}{$\mathrm{MC}_{p}$} \\
\hline & No. & $\%$ & No. & $\%$ & No. & $\%$ & To. & $0 / 0$ & & \\
\hline \multicolumn{11}{|l|}{ Killip class: } \\
\hline 1 & 85 & 85.0 & 42 & 97.7 & 31 & 88.6 & 12 & 54.5 & 21.771 & $<0.001$ \\
\hline $2-4$ & 15 & 15.0 & 1 & 2.3 & 4 & 11.4 & 10 & 45.5 & & \\
\hline \multicolumn{11}{|c|}{ STEMI location: } \\
\hline Anterior & 54 & 54.0 & 12 & 27.9 & 22 & 62.9 & 20 & 90.9 & 31.611 & $<0.001$ \\
\hline Inferior & 37 & 37.0 & 27 & 62.8 & 10 & 28.6 & 0 & 0.0 & & \\
\hline Lateral & 9 & 9.0 & 4 & 9.3 & 3 & 8.6 & 2 & 9.1 & & \\
\hline
\end{tabular}

According to angiographic results: The Left Anterior Descending (LAD) was the culprit vessel in $50 \%$ of cases, Right Coronary Artery (RCA) was the culprit in $30 \%$ of cases, while the Left Circum Flex (LCX) was the culprit in $20 \%$ of cases. with significant statistical differences among the three studied groups ( $p$-value ${ }^{\left.<0.001^{*}\right) \text {, }}$ regarding number of diseased vessels $49 \%$ of cases were single vessel, and $51 \%$ were multi vessel with significant statistical differences among the three studied groups ( $p$-value ${ }^{\left.<.001^{*}\right)}$ and regarding final TIMI flow 19 patients of the study population had a final TIMI flow $<3(19 \%)$ and the rest of the patients $(81 \%)$ had a final TIMI III flow, with statistically significant difference between the studied groups ( $p$-value $<0.001)$, Table (5).

Table (5): Comparison between the different studied groups according to angiographic results.

\begin{tabular}{|c|c|c|c|c|c|c|c|c|c|c|}
\hline & \multicolumn{2}{|c|}{$\begin{array}{c}\text { Total } \\
(\mathrm{n}=100)\end{array}$} & \multicolumn{2}{|c|}{$\begin{array}{l}\text { Group I } \\
(n=43)\end{array}$} & \multicolumn{2}{|c|}{$\begin{array}{l}\text { Group II } \\
(\mathrm{n}=35)\end{array}$} & \multicolumn{2}{|c|}{$\begin{array}{c}\text { Group III } \\
(\mathrm{n}=22)\end{array}$} & \multirow[t]{2}{*}{$\chi^{2}$} & \multirow[t]{2}{*}{$\mathrm{MC}_{p}$} \\
\hline & No. & $\%$ & No. & $\%$ & No. & $\%$ & No. & $\%$ & & \\
\hline \multicolumn{11}{|c|}{ Infarction related artery: } \\
\hline LAD & 50 & 50.0 & 12 & 27.9 & 21 & 60.0 & 17 & 77.3 & $23.968 *$ & $<0.001 *$ \\
\hline RCA & 30 & 30.0 & 23 & 53.5 & 7 & 20.0 & 0 & 0.0 & & \\
\hline LCX & 20 & 20.0 & 8 & 18.6 & 7 & 20.0 & 5 & 22.7 & & \\
\hline \multicolumn{11}{|c|}{ Number of diseased vessels: } \\
\hline Single vessel & 49 & 49.0 & 30 & 69.8 & 18 & 51.4 & 1 & 4.5 & $24.901 *$ & $<0.001 *$ \\
\hline Multi vessel & 51 & 51.0 & 13 & 30.2 & 17 & 48.6 & 21 & 95.5 & & \\
\hline \multicolumn{11}{|l|}{ Final TIMI flow: } \\
\hline$<3$ & 19 & 19.0 & 2 & 4.7 & 3 & 8.6 & 14 & 63.6 & $36.707^{*}$ & $<0.001 *$ \\
\hline 3 & 81 & 81.0 & 41 & 95.3 & 32 & 91.4 & 8 & 36.4 & & \\
\hline
\end{tabular}

\section{Laboratory parameters:}

As regarding the hemoglobin level, it ranged from $9.0-16.0 \mathrm{gm} / \mathrm{dl}$, with a mean of $12.03 \pm 1.58$. There was astatistically significant difference between the studied groups ( $p$-value $=0.007)$. The lymphocyte of the studies population ranged from $0.85-3.70\left(\mathrm{X} \mathrm{10}^{3} / \mathrm{mm}^{3}\right)$ with a mean of $2.36 \pm$ 0.64 . In Group I, the lymphocyte ranged from 1.70$3.70\left(X_{10} / \mathrm{mm}^{3}\right)$ with a mean of $2.70 \pm 0.56$. In Group II, the lymphocytes ranged from 1.50$3.70\left(X_{10} / \mathrm{mm}^{3}\right)$ with a mean of $2.33 \pm 0.57$. In Group III, the lymphocyte ranged from 0.85-2.60 (X $10 \% \mathrm{~mm}^{3}$ ) with a mean of $1.75 \pm .40$. There was statistically significant difference between the studied groups ( $p$-value $>0.001$ ), Table (6), with a negative correlation between lymphocyte and Gensini score, Fig. (1).

The platelets count of the studięd population ranged from $90.0-342.0\left(X_{10} / \mathrm{mm}^{3}\right)$ with a mean of 178.74 $\pm 61_{3} .50$. In Group I, it ranged from 90.0$320.0\left(\mathrm{X} \mathrm{10}^{2} / \mathrm{mm}^{3}\right)$ with a mean of $151.28+44.71$. In Group II, it ranged from $90.0-310.0\left(X_{10} / \mathrm{mm}^{3}\right)$ with mean 166.26 \pm 47.39 In Group III, it ranged from 170.0-342.0 (X 10 $\left./ \mathrm{mm}^{3}\right)$ with a mean of $252.27 \pm 52.21$. There was a statistically significant difference between the studied groups ( $p$-value $>0.001)$. Table (6). With positive correlation between platelets and Gensini score. Fig. (2). 
Table (6): Comparison between the different studied groups according to CBC.

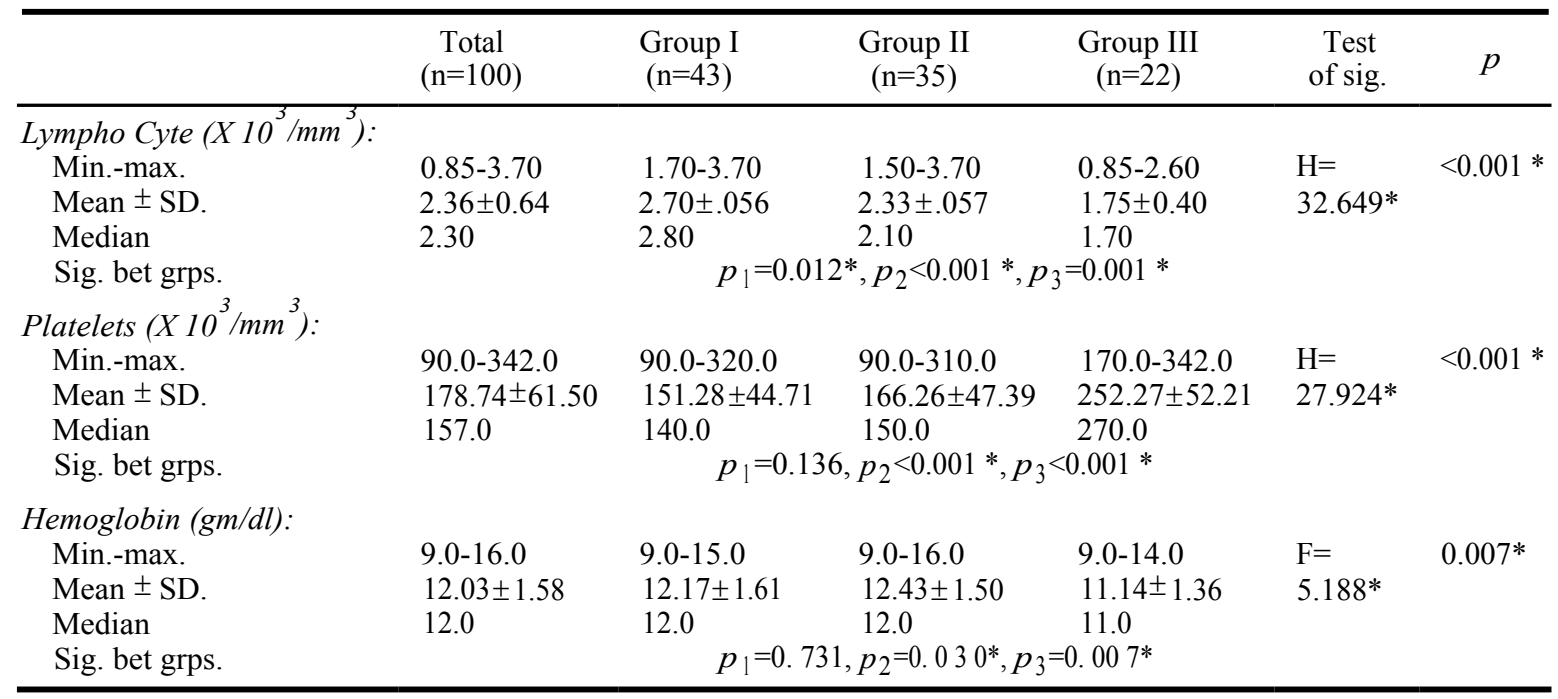

F : ANOVA test pair wise comparison bet. each 2 groups was done using Post Hoc Test (Tukey).

$\mathrm{H}$ : Kruskal Wallis test pair wise comparison bet. each 2 groups was done using post Hoc test (Dunn's for multiple comparisons test). $p: p$-value for comparing between the three groups.

$p 1: p$-value for comparing between Group I and Group II.

p2: $p$-value for comparing between Group I and Group III.

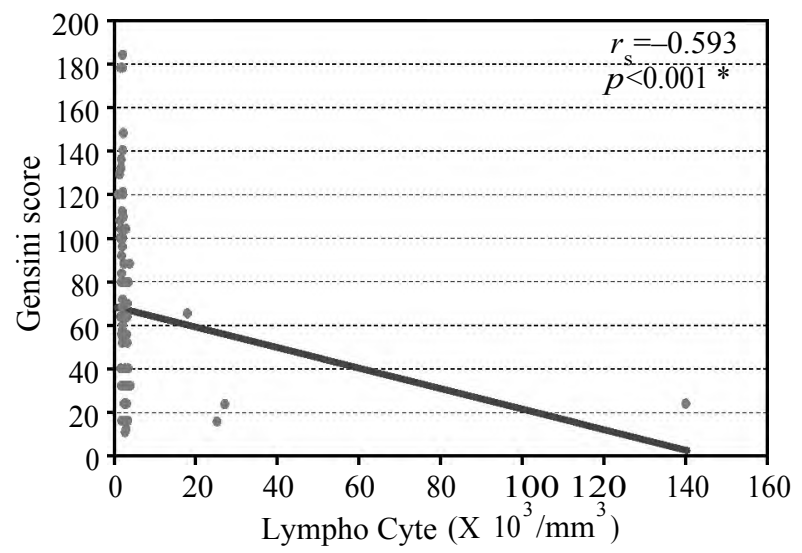

Fig. (1): Correlątion bुetween Gensini Score and Lymphocyte (X $10 \%$ mm ) in total sample.

\section{Lipid profile:}

Regarding the High-Density Lipoprotein (HDL), it ranged between $25.0-70.0 \mathrm{mg} / \mathrm{dl}$, with a mean of $42.62 \pm 7.94$, there was a statistically significant difference between the studied groups with patients in Group III had lower HDL level ( $p$-value $=0.001$ ). Regarding the Low Density Lipoprotein (LDL), it ranged between $90.0-230.0 \mathrm{mg} / \mathrm{dl}$ with a mean of $165.5 \pm 24.57$. There was a statistically significant difference between the studied groups with patients in Group III had higher LDL level ( $p$-value $=0.005)$, and regarding the triglycerides, it ranged between $80.0-250.0 \mathrm{mg} / \mathrm{dl}$ with a mean of $165.8 \pm 32.92$ there was statistically significant difference between the studied groups ( $p$-value $<0.001^{*}$ ), Table (7).

$$
\begin{aligned}
& p 3: p \text {-value for comparing between Group II and Group III. } \\
& * \text { : Statistically significant at } p \leq 0.05 \text {. }
\end{aligned}
$$

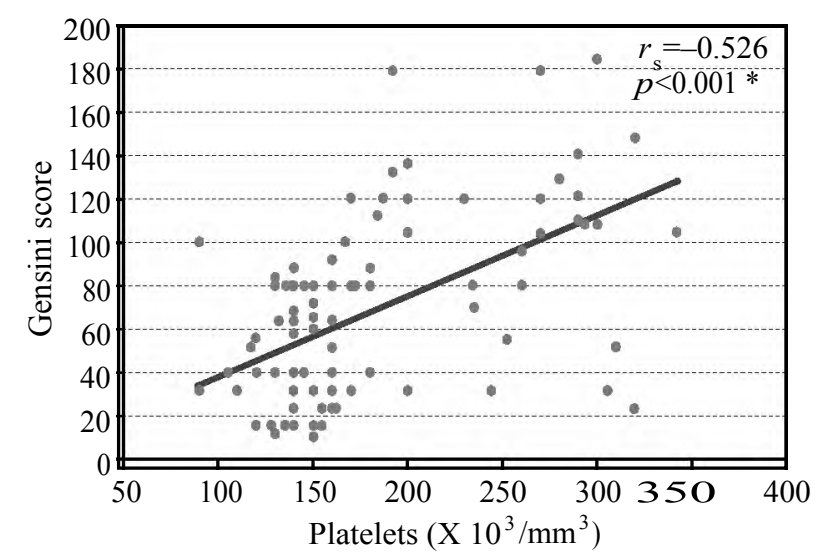

Fig. (2): Correlation between Gensini Score and Platelets (X $\left.10 / \mathrm{mm}^{3}\right)$ in total sample $(\mathrm{n}=100)$.

In hospital Major Adverse Cardiac Events (MACE): Regarding death, 9 patients $(9 \%)$ of the study population died during the hospital stay with statistically significant difference between the studied groups ( $p$-value $<0.001)$. Regarding re-infarction, 7 patients of the study population developed re-infarction during the hospital stay (7\%). The incidence of in-hospital re-infarction increased from group one to group three, there was a statistically significant difference between the studied groups ( $p$-value $<0.001)$. Regarding Congestive Heart Failure (CHF), 14 patients (14\%) in our study suffered from CHF during the hospital stay. There was a statistically significant difference between the studied groups with the prevalence of in-hospital CHF increased from group one to group three, $(p$-value $<0.001)$, Table $(8)$. 
Table (7): Comparison between the different studied groups according to lipid profile.

\begin{tabular}{|c|c|c|c|c|c|c|}
\hline & $\begin{array}{c}\text { Total } \\
(\mathrm{n}=100)\end{array}$ & $\begin{array}{c}\text { Group I } \\
(n=43)\end{array}$ & $\begin{array}{c}\text { Group II } \\
(\mathrm{n}=35)\end{array}$ & $\begin{array}{c}\text { Group III } \\
(n=22)\end{array}$ & $\mathrm{F}$ & $p$ \\
\hline \multicolumn{7}{|l|}{$H D L(m g / d l):$} \\
\hline Min.-max. & $25.0-70.0$ & $35.0-70.0$ & $30.0-55.0$ & $25.0-50.0$ & \multirow[t]{4}{*}{$13.084^{*}$} & \multirow[t]{4}{*}{$<0.001 *$} \\
\hline Mean \pm SD. & $42.62 \pm 7.94$ & $46.42 \pm 7.80$ & $41.37 \pm 6.61$ & $37.18 \pm 6.45$ & & \\
\hline Median & 40.0 & & 40.0 & 39.50 & & \\
\hline Sig. bet grps. & \multicolumn{4}{|c|}{$p_{1}=0.007^{*}, p_{2}<0.001 *, p_{3}=0.083$} & & \\
\hline \multicolumn{7}{|l|}{$L D L(m g / d l):$} \\
\hline Min.-max. & $90.0-230.0$ & $110.0-200.0$ & $90.0-200.0$ & $150.0-230.0$ & \multirow[t]{4}{*}{$5.692 *$} & \multirow[t]{4}{*}{$0.005^{*}$} \\
\hline Mean \pm SD & $165.5 \pm 24.57$ & $161.5 \pm 20.77$ & $161.1 \pm 26.61$ & $180.4 \pm 23.19$ & & \\
\hline Median & 170.0 & 170.0 & 170.0 & 180.0 & & \\
\hline Sig. bet grps. & \multicolumn{4}{|c|}{$p_{1}=0.996, p_{2}=0.008^{*}, p_{3}=0.009^{*}$} & & \\
\hline \multicolumn{7}{|l|}{ Triglycerides $(\mathrm{mg} / \mathrm{dl})$ : } \\
\hline Min.-max. & $80.0-250.0$ & $80.0-200.0$ & $105.0-220.0$ & $100.0-250.0$ & \multirow[t]{4}{*}{$8.917^{*}$} & \multirow[t]{4}{*}{$<0.001 *$} \\
\hline Mean \pm SD. & $165.8 \pm 32.92$ & $156.3 \pm 27.35$ & $162.7 \pm 29.85$ & $189.5 \pm 37.09$ & & \\
\hline Median & 160.0 & 160.0 & 165.0 & 195.0 & & \\
\hline Sig. bet grps. & \multicolumn{4}{|c|}{$p_{1}=0.626, p_{2}<0.001 *, p_{3}=0.005^{*}$} & & \\
\hline
\end{tabular}

F : ANOVA test pair wise comparison bet. each 2 groups was done using Post Hoc Test (Tukey).

$p: p$-value for comparing between the three groups.

p1: $p$-value for comparing between Group I and Group II.

$p 2: p$-value for comparing between Group I and Group III.

p3: $p$-value for comparing between Group II and Group III

*: Statistically significant at $p \leq 0.05$.

Table (8): Comparison between the different studied groups according to in-hospital (MACE).

\begin{tabular}{|c|c|c|c|c|c|c|c|c|c|c|}
\hline & \multicolumn{2}{|c|}{$\begin{array}{c}\text { Total } \\
(n=100)\end{array}$} & \multicolumn{2}{|c|}{$\begin{array}{l}\text { Group I } \\
(\mathrm{n}=43)\end{array}$} & \multicolumn{2}{|c|}{$\begin{array}{c}\text { Group II } \\
(\mathrm{n}=35)\end{array}$} & \multicolumn{2}{|c|}{$\begin{array}{c}\text { Group III } \\
(\mathrm{n}=22)\end{array}$} & \multirow[t]{2}{*}{$x^{2}$} & \multirow[t]{2}{*}{$\mathrm{MC}_{p}$} \\
\hline & No. & $\%$ & No. & $\%$ & No. & $\%$ & No. & $\%$ & & \\
\hline In hospital death & 9 & 9.0 & 0 & 0.0 & 1 & 2.9 & 8 & 36.4 & $19.613^{*}$ & $<0.001 *$ \\
\hline In-hospital reinfection & 7 & 7.0 & 0 & 0.0 & 1 & 2.9 & 6 & 27.3 & $13.427^{*}$ & $<0.001 *$ \\
\hline In-hospital CHF & 14 & 14.0 & 0 & 0.0 & 3 & 8.6 & 11 & 50.0 & $26.904 *$ & $<0.001 *$ \\
\hline
\end{tabular}

\section{Univariate and multivariate analysis of Gensini} score:

Univariate and multivariate regression analyses were performed to investigate the possible predictive value for severity and complexity of angiographic result in the study population.

In univariate regression analysis, platelet, lymphocytes, PLR, HDL, LDL, triglycerides, in- hospital death, in-hospital re-infarction, in-hospital CHF. Were correlated with gensini score, Table (9).

In the multivariate regression analysis, using model adjusted for previously mentioned parameters, pulse, random blood sugar, PLR independently predicted severity and complexity of angiographic result in STEMI.

Table (9): Multivariate linear regression analysis for Gensini Score in total sample $(n=100)$.

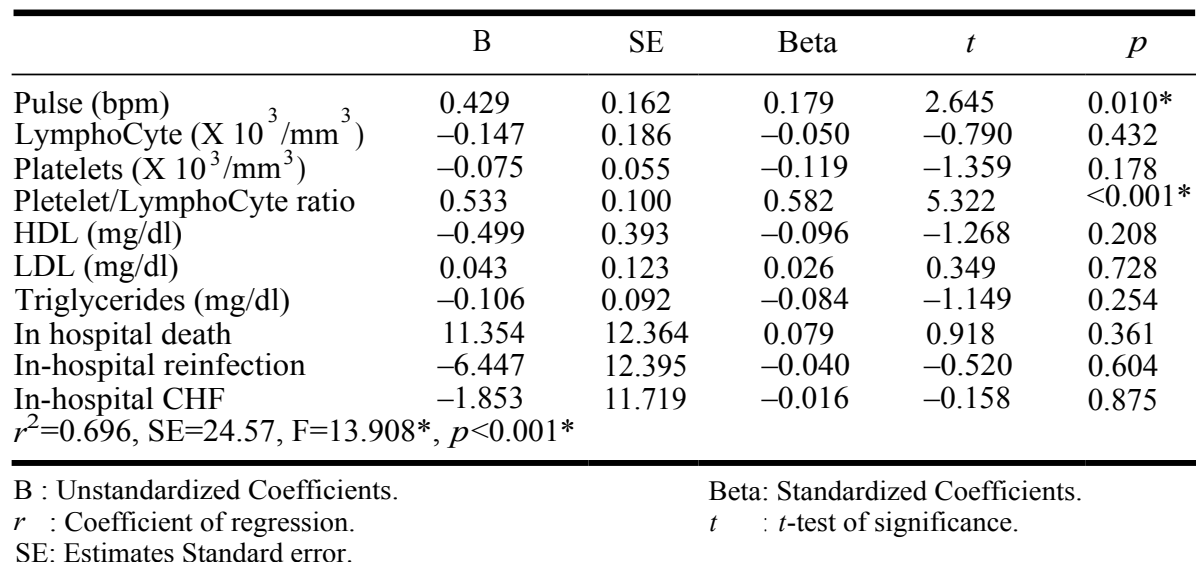


PLR:

As regarding relation between PLR and Gensini Score we divided sample to three tertile. In tertile 1 thirty-two patient ranged from 12 to 100 with mean $(37.63 \pm 22.21)$. In tertile 2 thirty-six patient ranged from 11 to 100 with mean $(54.57 \pm 24.75)$.
In tertile 3 thirty-two patient ranged from 32 to 184 with mean $(109.66 \pm 36.26)$ there was a statistically significant difference between the three groups ( $p$-value $<0.001$ ) Table $(10)$. With positive correlation between PLR and Gensini score, Fig. (3), Table (10).

Table (10): Relation between PLR and Gensini Score in total sample $(\mathrm{n}=100)$.

\begin{tabular}{|c|c|c|c|c|c|}
\hline & \multicolumn{3}{|c|}{ PLR } & \multirow{2}{*}{$\mathrm{H}$} & \multirow[b]{2}{*}{$p$} \\
\hline & $\begin{array}{l}1 \text { st tertile } \\
(\mathrm{n}=32)\end{array}$ & $\begin{array}{l}\text { 2nd tertile } \\
\quad(n=36)\end{array}$ & $\begin{array}{c}3^{\text {rd }} \text { tertile } \\
\quad(n=32)\end{array}$ & & \\
\hline $\begin{array}{l}\text { Gensini Score: } \\
\text { Min.-max. } \\
\text { Mean } \pm \text { SD. } \\
\text { Median } \\
\text { Sig. bet grps. }\end{array}$ & $\begin{array}{l}12.0-100.0 \\
37.63 \pm 22.21 \\
32.0\end{array}$ & $\begin{array}{l}11.0-100.0 \\
54.57 \pm 24.75 \\
59.0\end{array}$ & $\begin{array}{l}32.0-184.0 \\
109.66 \pm 36.26 \\
111.0\end{array}$ & $50.503 *$ & $<0.001 *$ \\
\hline $\begin{aligned} & \mathrm{H}: \text { Kruskal Wall } \\
& \text { (Dunn's for } \mathrm{m} \\
& p: p \text {-value for co } \\
& p_{1}: p \text {-value for co } \\
& p_{2}: p \text {-value for cc } \\
& p_{*} 3: p \text {-value for cc } \\
&: \text { Statistically } \mathrm{s}\end{aligned}$ & $\begin{array}{l}\text { test pairwise con } \\
\text { ultiple compariso } \\
\text { mparing between } \\
\text { mparing between } \\
\text { mparing between } \\
\text { mparing between } \\
\text { gnificant at } p \leq 0 \text {. }\end{array}$ & $\begin{array}{l}\text { nparison bet. eacl } \\
\text { ns test). } \\
\text { the three groups } \\
1 \text { st and 2nd. } \\
1 \text { st and 3rd. } \\
\text { 2nd and 3rd. } \\
5 .\end{array}$ & 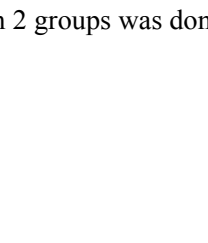 & using Pos & t Hoc Test \\
\hline
\end{tabular}

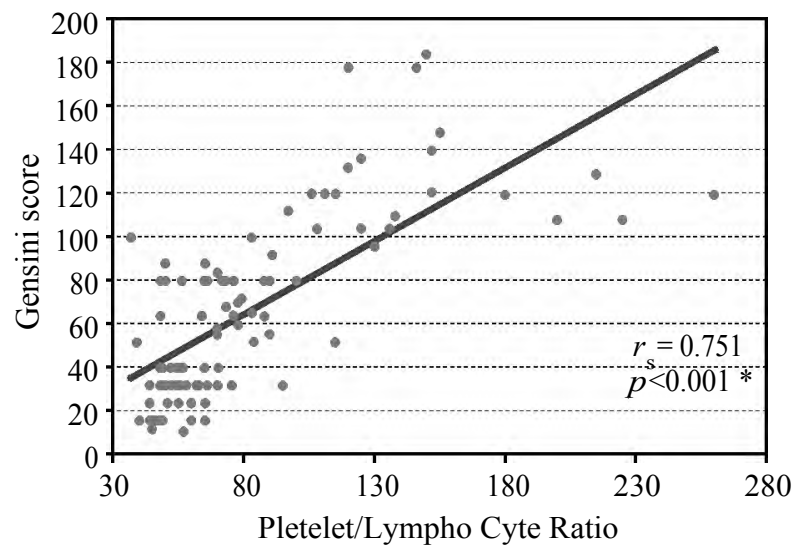

Fig. (3): Correlation between Gensini Score and Platelet/ Lymphocyte Ratio in total sample $(\mathrm{n}=100)$.

Table (11): Agreement (sensitivity, specificity) PLR to predict moderate and severe Vs. mild cases.

\begin{tabular}{llcccc}
\hline & Cutoff & Sensitivity & Specificity & PPV & NPV \\
\hline PLR & $>63$ & 87.72 & 81.40 & 86.2 & 83.3 \\
\hline AUC & $:$ Area Under a Curve. & & & \\
CI & : Confidence Intervals. & & & \\
$p$-value : Probability value. & & & &
\end{tabular}

The Receiver Operating Characteristics (ROC) analysis showing the performance and predictive accuracy of PLR in prediction moderate and severe Vs. mild. The Area Under the Curve (AUC) was $0.884(p<0.001)$ with cut off $>63$. With $87.72 \%$ sensitivity and $81.40 \%$ specificity.

The ROC analysis showing the performance and predictive accuracy of PLR in prediction severe cases Vs. mild and moderate. The Area Under the Curve (AUC) was $0.992(p<0.001)$ with cut off $>97$. With $87.72 \%$ sensitivity $95.45 \%$ and $96.15 \%$ specificity.

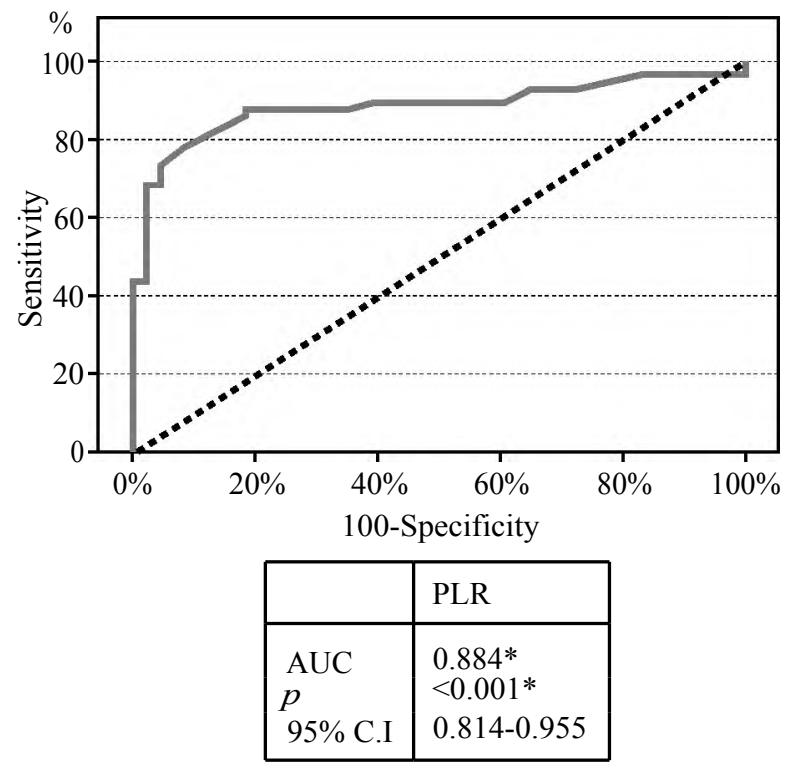

Fig. (4): ROC curve for PLR to predict moderate and severe Vs. mild.

Table (12): Agreement (sensitivity, specificity) PLR to predict severe cases Vs. mild + moderate.

\begin{tabular}{lccccc}
\hline & Cutoff & Sensitivity & Specificity & PPV & NPV \\
\hline PLR & $>97$ & 95.45 & 96.15 & 87.5 & 98.7 \\
\hline AUC & : Area Under a Curve. & & & \\
CI & : Confidence Intervals. & & & \\
$p$-value $:$ Probability value. & & & &
\end{tabular}




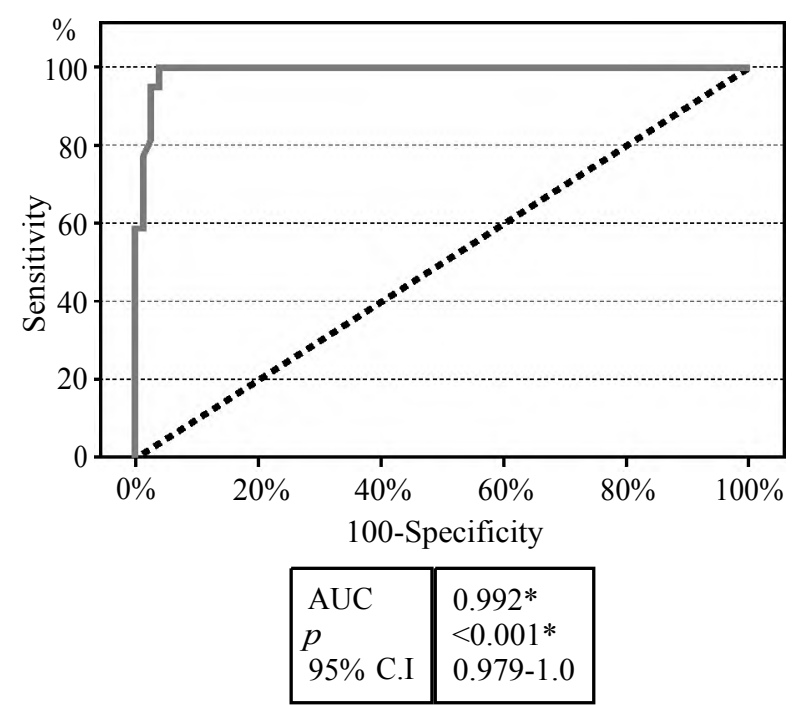

Fig. (5): ROC curve for PLR to predict severe cases Vs. mild + moderate.

\section{Discussion}

Worldwide, CAD is the most frequent cause of death that characterized pathologically by atherosclerosis formation [1].

The chronic inflammatory response is associated with production of platelets and lymphocytes. Elevated platelet counts accelerate atherosclerosis formation, progression, and destabilization of atherosclerotic plaques. Platelets act as a bridge between local inflammation at the vascular wall and development of atherosclerotic plaques [2] .

Low lymphocyte count accelerates the progression of atherosclerosis and worse cardiovascular consequences in patients with CAD. Therefore, the ratio of absolute number of platelets to the number of lymphocyte (PLR) acts as an effective biomarker to predict the severity of CAD [5].

Besides these risk scoring systems, the Gensini score is used to assess the angiographic characteristics and severity of coronary artery lesions in patients who undergo a primary PCI [6].

The aim of this work to assess relation between platelet to lymphocyte ratio with severity and complexity of coronary heart disease in patients with STEMI undergoing primary PCI intervention by using Gensini score.

The study was conducted in the Cardiovascular Department, Tanta University Hospitals. It was carried out on 100 adult patients of both gender diagnosed definitively with STEMI. The sample was divided according to angiographic severity of coronary artery disease by using Gensini score into three groups:

1- Group I (Gensini score from zero to 50).

2- Group II (Gensini score from 50 to 100).

3- Group III (Gensini score more than 100).

In the present study, as regard to age it was found that, in Group I the age of the patients ranged from 34-80 years with a mean age of $55.91 \pm 10.51$ years. In Group II the age ranged from 30-85 years with a mean age of $56.97 \pm 12.52$ years. In Group III the age ranged from 45-85 years with a mean age of $59.23 \pm 11.33$ years. There was no statistical significant difference between the three groups as regard the age $(p$-value $=0.543)$.

In contrast to the present study; Yüksel et al., in 2015 aimed to evaluate the relation of PLR to severity of CAD. They included 388 patients who developed CAD and then according to their coronary angiography, patients were categorized into three groups. The first group consisted of 80 patients with normal coronary arteries (control group). The rest of the patients with coronary artery disease were divided into two groups according to their Gensini score: Those with mild atherosclerosis $(n=156$; Gensini score $<25$ points $)$ and severe atherosclerosis ( $\mathrm{n}=152$; Gensini score $\geq 25$ points). [7], their results showed that their patients were older with mean age $62 \pm 12$ years. There was a statistical significant difference between the three groups ( $p$-value $<0.001)$.

As regard gender, the present study included 76 males and 24 females. Group I included 32 males $(74.4 \%$ and 11 females $(25.6 \%)$, Group II included 28 males $(80 \%)$ and 7 females $(20 \%)$, Group III included 16 males (72.7\%) and 6 females $(27.3 \%)$. There was no statistical significant difference between the three groups as regard the gender ( $p$-value $=0.781)$. Similarly in 2017 Zhou et al., aimed to evaluate the relation between RLR with the severity of CAD in Chinese people and included 854 patients who developed CAD. Their study showed that no statistically significant difference as regard the gender $(p$-value $=0.098)[8]$

As regard smoking, there was no statistical significant difference between the studied groups $(p=0.223)$. These results were similar to those of Yüksel et al., $(p$-value $=0.237)$ [7]

In the present study, as regard to DM, 20.9\% of patients in Group I were found to be diabetics, $31.4 \%$ of patients in Group II were diabetics and $50 \%$ of patients in Group III. There was no statistical significant difference between the overall 
incidence of diabetes mellitus in the studied groups $(p$-value $=0.056)$. These results were similar to those of Yüksel et al., ( $p$-value $=0.412)$ [7].

In contrast to the present study in 2017 Zhou et al., showed that DM significantly higher in the three vessel group than in the group with normal coronaries $(p$-value $<0.001)$ [8]

In the present study, as regard to hypertension, $25.6 \%$ of patients in Group I were found to be hypertensive, $31.4 \%$ of patients in Group II were hypertensive, while $45.5 \%$ of patients in Group III were hypertensive. There was no significant statistical difference among studied groups regarding hypertension. ( $p$-value $=0.266)$. These results were similar to those of Yuksel et al., $(p$-value $=$ $0.105)[7]$.

Regarding heart rate patients with severe angiographic results (Group III) were more likely to have higher heart rate $(p$-value $=<0.001)$ than those with mild angiographic result (Group 1) and (Group II) with (median $=80 \mathrm{~b} / \mathrm{m})$.

In the present study regarding Killp classification 85 patients of the study population presented with Killip class I (85\%) while 15 patients presented with Killip class of II-IV (15\%). There was a statistically significant difference between the studied groups ( $p$-value $<0.001$ ).

Regarding STEMI location in the present study 54 patients of the study population presented with anterior STEMI (54\%) while 37 patients presented with inferior STEMI (37\%) and 9 patients presented with lateral STEMI (9\%). There was a statistically significant difference between the three groups ( $p$ value $<0.001)$.

It is similarly to Cuneyt Toprak et al., who evaluate the association of PLR with angiographic coronary blood flow as well as the in-hospital and long-term outcome in patients with STEMI undergoing primary PCI. The study was composed of 408 consecutive patients diagnosed definitively with STEMI. Among these, 104 patients were excluded because of not receiving primary PCI [9]. Their results showed that anterior STEMI represented in 160 patient while inferior STEMI was represented in 101 patient ( $p$-value <0.001).

Regarding infarction related artery in Group I the culprit vessel was LAD in $27.9 \%$ of cases, RCA in 53.5\%, and CX 18.6\% are CX. In Group II the culprit vessel was LAD in $60 \%$ of cases are LAD, RCA in $20 \%$ are CX in $20 \%$. In Group III the culprit vessel was LAD $77.3 \%$ of cases, RCA in $0 \%$, and CX $22.7 \%$ with significant statistical differences among the three studied groups ( $p$ value $<0.001$ ). These results were similar to the result of Cuneyt Toprak et al., who showed that LAD is the most commonly affected vessel then RCA and LCX respectively with a statistically significant difference ( $p$-value $<0.001)$.

With regard to number of diseased vessels in Group I $69.8 \%$ of patients were found to single vessel disease while $30.2 \%$ of patients were found to have multi vessel disease. In Group II $51.4 \%$ of patients were found to single vessel disease while $48.6 \%$ of patients were found to have multi vessel disease. In Group III $4.5 \%$ of patients were found to single vessel disease while $95.5 \%$ of patients were found to have multi vessel disease, with significant statistical differences among the three studied groups ( $p$-value $<0.001$ ). These results were similar to the result of Cuneyt Toprak et al., who showed that severity of CAD correlated with number of diseased vessels with statistically significant difference between the studied groups ( $p$ value $=0.01)[9]$.

Regarding the final TIMI flow 19 patients of the study population had a final TIMI flow $<3$ $(19 \%)$ and the rest of the patients $(81 \%)$ had a final TIMI III flow, in Group 1, only two patients had a final TIMI flow $<3$ (4.7\%). In Group II, 3 patients had TIMI flow $<3(8.6 \%)$. In Group III, 14 patients had a final TIMI flow $<3(63.6 \%)$. There was a statistically significant difference between the studied groups ( $p$-value $<0.001)$. These results were similar to those of Cuneyt Toprak et al., who showed a statistically significant difference between the studied groups ( $p$-value $<0.001)$.

In the present study regarding the hemoglobin level of the studied population the level ranged from $9-16.0 \mathrm{gm} / \mathrm{dl}$ with a mean of $12.031 \pm 1.58$. There was statistically significant difference between the studied groups ( $p$-value $=0.007)$. In contrast to the present study, Yüksel et al., showed that hemoglobin levels were similar between all three groups $(p$-value $=0.548)$ [7]

In the present study regarding the lymphocyte of the studied population it ranged from 0.85-3.70 (X $10^{3} / \mathrm{mm}^{3}$ ) with a mean of $2.36 \pm 0.64$. In Group I, the lymphocyte ranged from 1.70-3.70 (X 10 3 $\mathrm{mm}^{3}$ ) with a mean of $2.70 \pm 0.56$. In Group $\mathrm{II}$, the Lymphocytes ranged from 1.50-3.70 (X $10 / \mathrm{mm}$ ) with a mean of $2.33 \pm 0.57$. In Group III, the Lym-

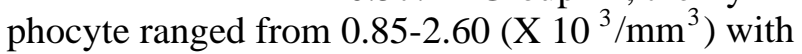
a mean of $1.75 \pm .40$. There was a statistically significant difference between the studied groups 
( $p$-value $>0.001)$. As shown in (Table 10) with negative correlation between lymphocyte and Gensini score.

In contrast to the present study, Yüksel et al., their study show lymphocyte count was comparable between all three groups $(p=0.337)$. Our results were similar to those of Zhou et al., in their study showed that lymphocyte has significant statistically difference $(p$-value $<0.001)$.

In the present study regarding the platelets count of the studied population, it ranged from $90.0-342.0\left(X_{10}^{3} / \mathrm{mm}^{3}\right)$ with a mean of 178.74 \pm 61.50 . In Group I, it ranged from 90.0-320.0 $\left(\mathrm{X} 10^{3} / \mathrm{mm}^{3}\right)$ with a mean of $151.28 \pm 44.71$. In Group II, it ranged from 90.0-310.0 (X 10 $\left.3 \mathrm{~mm}^{3}\right)$ with mean 166.26 $\pm 47.39{ }_{3}$ In Group III, it ranged from 170.0-342.0 (X $10 \%$ mm ) with a mean of $252.27 \pm 52.21$. There was a statistically significant difference between the studied groups ( $p$-value $>0.001$ ). Our results were similar to those of Zhou et al., and Yüksel et al., who showed that there was a significant statistically difference between the studied groups as regard the platelet count ( $p$ value $<0.001)[8]$.

Regarding PLR we divided sample to three tertile. In tertile 132 patient ranged from 12 to 100 with mean $(37.63 \pm 22.21)$. In tertile 236 patient ranged from 11 to 100 with mean $(54.57 \pm 24.75)$. In tertile 332 patient ranged from 32 to 184 with mean (109.66 \pm 36.26$)$. There was a statistically significant difference between the three groups ( $p$ value $<0.001)$.

It is similar to Yüksel et al., who showed that PLR was significantly higher in the severe atherosclerosis group compared to the mild atherosclerosis $(p<0.001)$.

Regarding lipid profile in the present study HDL of the studied group ranged from 25.0-70.0 $\mathrm{mg} / \mathrm{dl}$ with a mean of $42.62 \pm 7.94$ with a statistically significant difference between the studied groups ( $p$-value $<0.001)$. With regard to LDL of the studied group it ranged from $90.0-230.0 \mathrm{mg} / \mathrm{dl}$ with a mean of $161.5 \pm 24.57$ with a statistically significant difference between the studied groups $(p$-value $=$ 0.005 ). Triglycerides of the studied population ranged from $80.0-250.0 \mathrm{mg} / \mathrm{dl}$ with a mean of 165.8 \pm 32.92 with a statistically significant difference between the studied groups ( $p$-value $<0.001)$. In contrast to our results Zhou et al., showed that there was no statistically significant difference between the studied groups regarding HDL ( $p$ value $=0.324)$ and LDL ( $p$-value $=0.806)[8]$.
Our results were similar to those of Yüksel et al., who showed that LDL and HDL level was significantly higher in the severe atherosclerosis group compared to the mild atherosclerosis ( $p$ $<0.001)$.

In the present study as regard to in-hospital death, 9 patients of the study population died during the hospital stay (9\%). The incidence of in-hospital death increased from group one to group three, in Group I, no one died during the hospital stay ( $0 \%)$, in Group II, only one patient died during the hospital stay (2.9\%), while in Group III, 8 patients died during the hospital stay $(36.4 \%)$. There was a statistically significant difference between the studied groups $(p$-value $<0.001)$.

It is similar to Cuneyt Toprak et al., who showed that during the in-hospital period, the incidence of Major Adverse Cardiovascular Events (MACE) and mortality were significantly higher in patients with no-reflow ( $p$-value $<0.001$ ).

The number of patients who died during the follow-up period was significantly higher in the no-reflow group compared to the group with normal TIMI flow.

In the present study as regard to the incidence of in-hospital (CHF): 14 patients of the study population suffered from CHF during the hospital stay $(14 \%)$ with a statistically significant difference between the studied groups ( $p$-value <0.001).

Regarding the in-hospital re-infarction: Seven patients of the study population developed reinfarction during the hospital stay (7\%). The incidence of in-hospital re-infarction increased from group one to group three, in Group I, no one suffered from re-infarction during the hospital stay $(0 \%)$. In Group II, only one patient (2.9\%). While in Group III, sex patients suffered from re-infarction during the hospital stay (27.3\%). There was a statistically significant difference between the studied groups ( $p$-value $<0.001)$.

These results were in contrast to the results of Cicek et al., who assessed the effect of combination of Neutrophil-Lymphocyte Ratio (NLR) and Platelet-Lymphocyte Ratio (PLR) in predicting inhospital and long-term mortality in patients $(\mathrm{n}=$ 2518) undergoing primary PCI. They did not find any significant relation between PLR and MACE [10].

According to our results, high levels of PLR were correlated with in-hospital MACE among patients with STEMI who undergo primary PCI. 


\section{Study limitations:}

There are several limitations regarding the present study:

- Sample size was small, enrolment was retrospective and it was a single center design.

- We used coronary angiography only to evaluate severity of coronary vessels without using other method such as intra vascular ultrasound or CT coronary angiography that provide necessary data about the extent of coronary atherosclerosis, the coronary plaque burden.

-We did not analyze other platelet indices including mean platelet volume, platelet distribution width.

- We had no data about inflammation markers including C-reactive protein, tumor necrosis factor-alpha.

\section{Conclusion:}

It was found that there is a significant association between high PLR and severity of CAD. PLR appears to be additive biomarker used in detection high-risk patients and this can add to early diagnosis of such patients with better management strategies.

\section{References}

1- WHO fact sheet. World Health Organization, 2017.

2- LIBBY P.: Inflammation in atherosclerosis. ArteriosclerThromb. Vasc. Biol., 32: 2045-51, 2012.

3- THAULOW E., ERIKSSEN J., SANDVIK L., STORMORKEN H. and COHN P.F.: Blood platelet count and function are related to total and cardiovascular death in apparently men. Circulation, 84: 613-7, 1991.

4- NUNEZ J., MINANA G., BODI V., NUNEZ E., SANCHIS J., HUSSER O. and LIACER A.: Low lymphocyte count and cardiovascular diseases Cur. Med. Chem., 18: 3226 33, 2011.

5- OMMEN S.R., GIBBONS R.J., HODGE D.O. and THOMSON S.P.: Usefulness of the lymphocyte concenrtration as a prognostic marker in coronary artery disease. Am. J. Cardiol., 812-4, 1997.

6- GENSINI G.G.: A more meaningful scoring system for determining severity of coronary heart disease. Am. J. Cardiol., 51: 606, 1983.

7- MURAT YÜKSEL, ABDULKADIR Y1LDiZ, MUSTAFA OYLUMLU, ABDURRAHMAN AKYÜZ, MESUTAYD1N, et al.: Association between Platelet-to-Lymphocyte Ratio (PLR) and the severity of atherosclerosis in coronary artery disease. Anatol. J. Cardiol., 15: 640-7, 2015.

8- ZHOU, et al.: Platelet to lymphocyte ratio is associated with coronary artery disease. Experimental and therapeutic medicine, 13: 731-8, 2017.

9- CUNEYT TOPRAK1, MEHMET M. TABAKCI1, ZEKI SIMSEK1, UGURARSLANTAS, HALIL I., et al.: Platelet/lymphocyte ratio was associated with impaired myocardial perfusion and both in-hospital and long-term adverse outcome in patients with ST-segment elevation acute myocardial infarction undergoing primary coronary intervention. Postep. Kardiol. Inter., 11, 4 (42): 288-97, 2015.

10- CICEK G., AC1KGOZ S.K., BOZBAY M., et al.: Neutrophil-lymphocyte ratio and platelet-lymphocyte ratio combination can predict prognosis in patients with STsegment elevation myocardial infarction undergoing primary percutaneous coronary intervention. Angiology, 66 (5): 441-7, 2015. 


\section{العلاقة بين الصفائح الدموية إلى نسبة اللمفاويات مع شدة إنداة

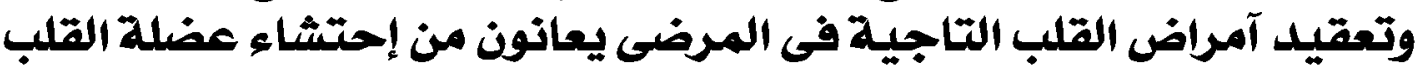 ويخضعون للقسطرة القلبية العلاجية العية الآولية احتية}

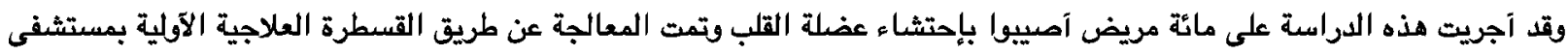
جامعة طنطا فى الفترة من يونيو Y Y. IV حتى نهاية ديسمبر من نفس العام.

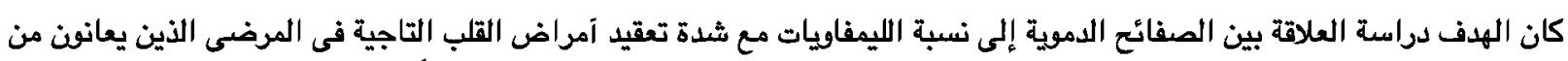

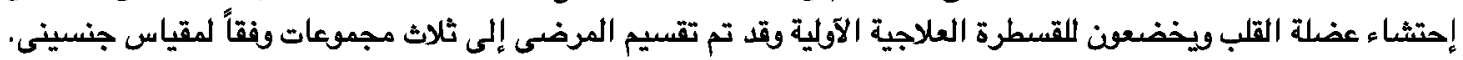
وقد شملت: المجموعة الآولى : ثلاثة وآريعين مريضاً وكانت تتراوح نقاطهم من صفر إلى خمسين. المجموعة الثانية: شملت خمسة وثلاثين مريضاً وكانت تتراوح نقاطهم من الخمسين إلى المائة. المجهوعة الثالثة: شملت إثنتى وعشرين مريضاً وكانت تتراوح نقاطهم آكثر من المائة.

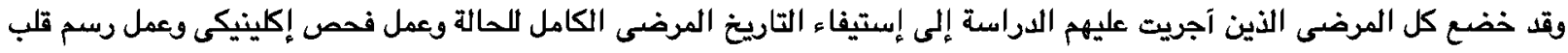

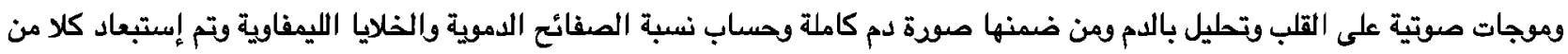

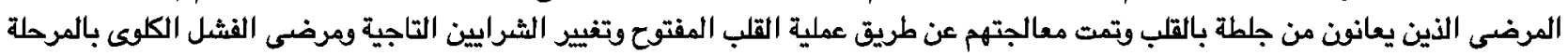
النهائية ومرضى الدين يعاني ومن الدضى الكبد والقنوات المرارية ومرضى السرطان والمرضى الذين تعرضوا حديثاً لجراحة آو راضخة كبرىى. وقد خلمت الدراسة آنه لا يوجد فرقق ذات دلالة إحصائية بين الثلاث مجموعات فيما يتعلق بالسن والجنس والآمراض الشائعة كمرض السكرى وإرتفاع ضغط الدم والتدخين.

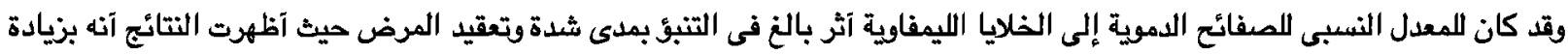

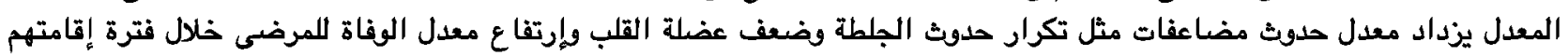

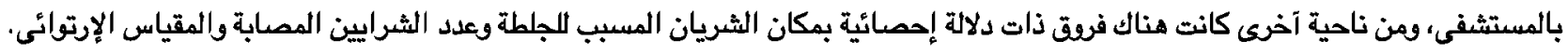
وقد خلصت النتائج إلى إمكانية إستخدام المعدل النسبى للصفائح الدموية إلى الخلايا الليمفاوية كمؤشر حيوى اللتنبؤ بمدى تعقد تصلب

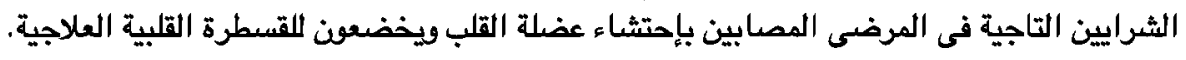

